УДК 378.016:611

\title{
ОРГАНІЗАЦІЯ НАВЧАЛЬНОГО ПРОЦЕСУ ЗА КРЕДИТНО- МОДУЛЬНОЮ СИСТЕМОЮ 3 АНАТОМІЇ ЛЮДИНИ
}

Н. І. Гаӥна, Т. В. Процак

Буковинський державний медичний університет, м. Чернівиі

\section{ORGANIZATION OF EDUCATIONAL PROCESS ACCORDING TO THE CREDIT TRANSFER SYSTEM ON HUMAN ANATOMY}

\author{
N. I. Haiina, T. V.Protsak \\ Bukovynian State Medical University, Chernivtsi
}

\begin{abstract}
Кредитно-модульна система (КМС) передбачає не стільки розподіл змісту навчання відповідних освітньо-професійних програм на модулі, як впровадження модульних технологій навчання, що передбачає обов'язковий розподіл кожного змістового модуля на навчальні елементи. Акцент підготовки фахівців переноситься з навчальних занять на самостійну роботу студента, що потребус допоміжного матеріально-технічного та навчально-методичного забезпечення. Впровадження кредитно-модульної системи в університеті підвищує якість вищої освіти фахівців і забезпечує на цій основі конкурентоспроможність випускників та престижу української вищої освіти у свропейському і світовому освітньому просторі.

Credit-transfer system (CTS) provides not only the distribution of learning content of appropriate educational and vocational programs into modules as the introduction of modular technology education, which includes mandatory sharing of content of each module on the educational elements. The focus of training shifted from training sessions on independent work of the student who needs support logistical and teaching provision. The introduction of credit-transfer system at the University enhances the quality of higher education professionals and provides on this basis competitiveness of graduates and the prestige of Ukrainian higher education in the European and world educational space.
\end{abstract}

Вступ. Згідно з основними нормативно-правовими документами, що регулюють організаційно-методичне забезпечення кредитно-модульної системи, це: накази Міністерства освіти і науки України № 48 від 23.01.2004 року “Про проведення педагогічного експерименту з кредитно-модульної системи організації навчального процесу”; № 49 від 23.01.2004 року “Про затвердження програми дій щодо реалізації положень Болонської конвенції в системі вищої освіти і науки України на 2004-2005 роки”; № 812 від 20.10.2004 року “Про особливості впровадження кредитно-модульної системи організації навчального процесу"; № 454 від 29.07.2005 року "Про невідкладні заходи щодо забезпечення функціонування та розвитку освіти в Україні”; № 774 від 30.12.2005 року "Про впровадження кредитномодульної системи організації навчального процесу" [1-6], Україна підтвердила наміри наслідувати міжнародні стандарти організації навчального процесу та мати можливість входження в європейський освітньо-науковий простір [7].

Буковинський державний медичний університет (БДМУ) здійснює модернізацію сучасної вищої освіти шляхом розширення використання новітніх освітніх і педагогічних технологій у межах Болонського процесу [8-10].

Основна частина. На кафедрі анатомії людини ім. М. Г. Туркевича БДМУ навчання за кредитномодульною системою проходить відповідно до основних положень та принципів: модульність, кредитність; методичне консультування та забезпечення; пріоритетність змістової й організаційної самостійності та зворотного зв'язку між студентом i викладачем; науковість; технологічність та інноваційність.

Навчальна програма 3 дисципліни "Анатомія людини" для студентів зі спеціальності "Лікувальна справа” структурована на п'ять модулів, до складу яких входять блоки змістових модулів, яких налічується сімнадцять. На вивчення дисципліни відводяться 230 навчальних годин.

Організація навчального процесу згідно з КМС спонукає студентів систематично готуватися впродовж навчального року. Навчальні заняття, згідно з навчальним планом, включають лекції, практичні заняття, самостійну роботу студентів.

У свою чергу, практичні заняття передбачають: знання студентами будови органів та систем органів 
людини; оцінювання вікових, статевих та індивідуальних особливостей будови органів людини; вирішення ситуаційних задач, які мають клініко-анатомічне обгрунтування.

Засвоєння теми контролюється на практичних заняттях відповідно до конкретних цілей.

Також застосовуються такі засоби діагностики рівня підготовки студентів: комп'ютерні тести, розв'язування ситуаційних задач, контроль практичних навичок, знання анатомічних препаратів 3 наступним аналізом і оцінюванням статевих, вікових, індивідуальних особливостей будови органів людини; аналіз топографо-анатомічних взаємовідношень органів i систем людини; аналіз закономірностей пренатального та раннього постнатального розвитку органів людини, варіантів їх мінливості та вад розвитку.

Лекційний курс розкриває проблемні питання відповідних розділів анатомії людини.

Підсумковий модульний контроль зараховується студенту, якщо він набрав не менше 50 із 80 балів. Це надає можливість виявити рівень теоретичної та практичної підготовки студента 3 кола питань, що вивчалися відповідно до програми модуля. Контроль проводиться шляхом усного опитування, написання письмових робіт, тестів, вирішення ситуаційних завдань, демонстрації практичних навичок.

Оцінка $з$ дисципліни виставляється лише студентам, яким зараховано всі модулі з даної дисципліни. Кількість балів, яку студент набрав $з$ дисципліни,

\section{Література}

1. Про проведення педагогічного експерименту з кредитно-модульної системи організації навчального процесу : наказ Міністерства освіти і науки України № 48 від 23.01.04.

2. Про затвердження програми дій щодо реалізації положень Болонської конвенції в системі вищої освіти і науки України на 2004-2005 роки : наказ Міністерства освіти і науки України № 49 від 23.01.04.

3. Про особливості впровадження кредитно-модульної системи організації навчального процесу : наказ Міністерства освіти і науки України № 812 від 20.10.04.

4. Про невідкладні заходи щодо забезпечення функціонування та розвитку освіти в Україні : наказ Міністерства освіти і науки України № 454 від 29.07.05.

5. Про впровадження кредитно-модульної системи організації навчального процесу : наказ Міністерства освіти і науки України № 774 від 30.12.05 визначається як середня арифметична кількості балів 3 усіх модулів дисципліни (сума балів за усі модулі ділиться на кількість модулів дисципліни).

Об'єктивність оцінювання навчальної діяльності студентів перевіряється статистичними методами (коефіцієнт кореляції між поточною успішністю та результатами підсумкового модульного контролю).

За рішенням Вченої ради ВНЗ, до кількості балів, яку студент набрав 3 дисципліни, можуть додаватися заохочувальні бали за публікації наукових робіт, отримання призових місць на олімпіадах за профілем дисципліни тощо. Також кафедрою передбачена індивідуальна робота студента: підготовка музейного препарату або макета органа з гіпсу, вирізьблення 3 дерева, що урізноманітнює колекцію анатомічного музею кафедри.

Оцінка успішності студента з дисципліни є рейтинговою і виставляється за багатобальною шкалою як середня арифметична оцінка засвоєння відповідних модулів і має визначення за системою ECTS та шкалою, прийнятою в Україні.

Висновок. Вищі медичні навчальні заклади повинні неухильно забезпечувати якісну підготовку медичних працівників, які володітимуть усім сучасним арсеналом новітніх технологій у діагностиці та лікуванні. Необхідно створити такі умови для організації навчального процесу, за яких кожен студент відчує реалізацію своїх знань, вмінь та навичок, свою успішність, активність.

6. Вища медична освіта України на сучасному етапі / В. В. Лазоришинець, М. В. Банчук, О. П. Волосовець [та ін.] // Проблеми сучасної медичної науки та освіти. - 2008. - № 4. - С. 5-10.

7. Медична освіта у світі та в Україні / [Ю.В.Поляченко, В. Г. Передерій, О. П. Волосовець та ін.]. -К. : Книга плюс, 2005. -383 c.

8. Лісовий В. М. Якість освіти в контексті Болонського процесу: реалії та перспективи / В. М. Лісовий, В. А. Капустник // Медична освіта. - 2010. - № 2. - С. 120-123.

9. Мілерян В. С. Методичні основи підготовки та проведення навчальних занять в медичних вузах / В. С. Мілерян. -Київ, 2006. -80 с.

10. Згуровський М. 3. Стан та завдання вищої освіти України в контексті Болонського процесу / М. З. Згуровський. - К. : Політехніка, 2004. -76 c. 